\title{
Convex Relaxations of Probabilistic AC Optimal Power Flow for Interconnected AC and
} HVDC Grids

\author{
Venzke, Andreas; Chatzivasileiadis, Spyros
}

Published in:

IEEE Transactions on Power Systems

Link to article, DOI:

10.1109/TPWRS.2019.2895122

Publication date:

2019

Document Version

Publisher's PDF, also known as Version of record

Link back to DTU Orbit

Citation (APA):

Venzke, A., \& Chatzivasileiadis, S. (2019). Convex Relaxations of Probabilistic AC Optimal Power Flow for Interconnected AC and HVDC Grids. IEEE Transactions on Power Systems, 34(4), 2706 - 2718.

https://doi.org/10.1109/TPWRS.2019.2895122

\section{General rights}

Copyright and moral rights for the publications made accessible in the public portal are retained by the authors and/or other copyright owners and it is a condition of accessing publications that users recognise and abide by the legal requirements associated with these rights.

- Users may download and print one copy of any publication from the public portal for the purpose of private study or research.

- You may not further distribute the material or use it for any profit-making activity or commercial gain

- You may freely distribute the URL identifying the publication in the public portal 


\title{
Correction to "Convex Relaxations of Probabilistic AC Optimal Power Flow for Interconnected AC and HVDC Grids"
}

\author{
Andreas Venzke, Student Member, IEEE, and Spyros Chatzivasileiadis, Senior Member, IEEE
}

In the article [1], there is a typo in the equation in (26) in Section III.A). The correct formula should read:

$$
N_{\mathrm{s}} \geq \frac{1}{\epsilon} \frac{e}{e-1}\left(\ln \frac{1}{\beta}+2 n_{\delta}-1\right)
$$

\section{REFERENCE}

[1] A. Venzke and S. Chatzivasileiadis, "Convex relaxations of probabilistic AC optimal power flow for interconnected AC and HVDC grids," IEEE Trans. Power Syst., vol. 34, no. 4, pp. 2706-2718, Jul. 2019. funded by Innovation Fund Denmark, Grant Agreement 6154-00020B.

The authors are with the Center for Electric Power and Energy, Technical University of Denmark, 2800 Lyngby, Denmark (e-mail: avenzke@gmx.net; spyros.chatz@gmail.com).

Digital Object Identifier 10.1109/TPWRS.2020.3011273 